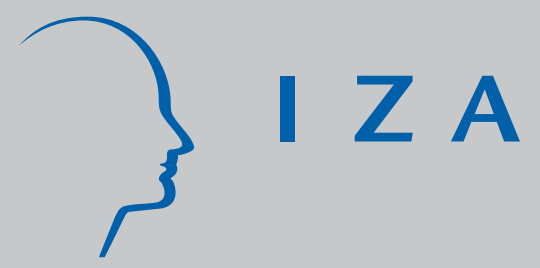

IZA DP No. 217

Occupational Gender Composition and Wages in Sweden

J örgen Hansen

Roger Wahlberg

November 2000 


\title{
Occupational Gender Composition and Wages in Sweden
}

\author{
Jörgen Hansen \\ Concordia University, IZA and CEPR \\ Roger Wahlberg \\ University of Gothenburg, Department of Economics \\ Discussion Paper No. 217 \\ November 2000 \\ IZA \\ P.O. Box 7240 \\ D-53072 Bonn \\ Germany \\ Tel.: +49-228-3894-0 \\ Fax: +49-228-3894-210 \\ Email: iza@iza.org
}

This Discussion Paper is issued within the framework of IZA's research area The Future of Work. Any opinions expressed here are those of the author(s) and not those of the institute. Research disseminated by IZA may include views on policy, but the institute itself takes no institutional policy positions.

The Institute for the Study of Labor (IZA) in Bonn is a local and virtual international research center and a place of communication between science, politics and business. IZA is an independent, nonprofit limited liability company (Gesellschaft mit beschränkter Haftung) supported by the Deutsche Post AG. The center is associated with the University of Bonn and offers a stimulating research environment through its research networks, research support, and visitors and doctoral programs. IZA engages in (i) original and internationally competitive research in all fields of labor economics, (ii) development of policy concepts, and (iii) dissemination of research results and concepts to the interested public. The current research program deals with (1) mobility and flexibility of labor markets, (2) internationalization of labor markets and European integration, (3) the welfare state and labor markets, (4) labor markets in transition, (5) the future of work, (6) project evaluation and (7) general labor economics.

IZA Discussion Papers often represent preliminary work and are circulated to encourage discussion. Citation of such a paper should account for its provisional character. 
IZA Discussion Paper No. 217

November 2000

\section{ABSTRACT}

\section{Occupational Gender Composition and Wages in Sweden*}

We estimate the relationship between wages and occupational gender segregation in Sweden. Because of high wage equality in Sweden compared to the U.S., we expect a lower wage penalty of job femaleness in Sweden than in the U.S. Our results supports this hypothesis. We also investigate how the unexplained gender wage gap vary across occupations and find that this gap is smallest in male dominated jobs and largest in female dominated jobs. Finally, we investigate whether the female wage-experience profiles are different across occupations. Our results indicate that women have flatter wage-experience profiles in female dominated occupations than in male dominated occupations.

JEL Classification: J31, J71

Keywords: occupational segregation, gender wage gap

Jörgen Hansen

Department of Economics

Concordia University

1455 de Maisonneuve Blvd W

Montreal, Quebec

Canada, H3G 1 M8.

E-mail: hansen@vax2.concordia.ca

\footnotetext{
* We thank Astrid Kunze, Magnus Lofstrom, Melanie Ward and participants at ESPE 2000 for valuable comments.
} 


\section{Introduction}

A well-established result in the empirical literature on the gender wage gap is that a signi..cant portion of this gap results from employer discrimination. This is a result that has been documented for most countries, see Blau and Kahn (1992 and 1996) for surveys. Most of the existing studies that try to estimate the unexplained portion of the gender wage gap are based on a sample of male and female workers and attempt to explain their wages by their observable characteristics, such as accumulated human capital (years of schooling and years of work experience) and other factors (such as marital status and labor supply) believed to infuence wages. A common result is that these characteristics explain about half of the dixerences in wages between women and men. The remaining portion of the wage gap is then often attributed to employer discrimination.

One natural candidate for explaining at least part of the unobserved dixerence in wages across gender is occupational segregation. There exist a general understanding that occupational segregation is present and that females are gathered disproportionally in occupations with lower earnings. However, there is no agreement on the cause of these outcomes and two contradicted theories have been given in the literature. The ...rst line argues that females are gathered disproportional in occupations with low earnings due to market discrimination and the second line argues that it is due to a self-sorting mechanism. Unfortunately, it has proven very dic cult to empirically test these two competing theories. ${ }^{1}$

Even if it is di $\pitchfork$ cult to establish the reasons for occupational segregation by gender, it may still be important to assess the impact of this kind of segregation on both wages and wage gaps. Recently, there have been a large number of studies devoted to empirically determining the impact of the density of females (FE M ) in a certain occupation on individual wages, see for instance B ayard et al (1999), M acpherson and Hirsch (1995), Sorensen (1990), Sorensen (1989), England et al (1988) and J ohnson and Solon (1986)

\footnotetext{
${ }^{1}$ The problem is similar to the one of the existence of dual labor markets. Dickens and Lang (1985) presents a model, which they argue is able to test the human capital theory against the dual labor market theory. However, there is no general agreement on the validity of their claim. Their model is able to test dixerence in wage distributions between a primary and a secondary labor market but not the reasons for the presence of this dixerence.
} 
for applications on U.S. data, Baker and Fortin (1999) using C anadian data, Miller (1987) using data from the U.K . and le Grand (1991) using Swedish data. The results from these studies are mixed but most of them suggest that there is a signi..cant and negative relationship between proportion of females in an occupation and wages. ${ }^{2}$

The objectives with this paper are as follows. First, we will obtain estimates of the exect of occupational segregation on male and female wages in Sweden and we will also compare our estimates with those reported in previous studies. Secondly, we will address the question of endogeneity of the F E M variable. This issue has received little attention in the previous literature. Third, we will test whether the returns to accumulated work experience for women dixer across occupations. Fourth, we are interested in analyzing what fraction of the observed gender wage gap is due to di xerences in endowments (usually referred to as the "explained" gender wage gap), occupational segregation and unobserved factors (of which labor market discrimination might be one).

A potential problem with most of the previous studies in this area is that they assume that occupational attainment can be treated as exogenous, i.e. there is no correlation between the density of females in an occupation and the error term in the wage equation. ${ }^{3}$ As argued by Macpherson and Hirsch (1995), there exist at least two reasons for why the exogeneity assumption may be false. First, if men and women with higher unmeasured skills (captured by the error term in the wage equation) are more likely to be sorted into male jobs and those with lower skills into female jobs, then the exogeneity assumption will obviously be violated. ${ }^{4}$ Second, the error term may also capture unobserved taste dixerences among workers. To illustrate this point, some female workers may foresee future work interruptions due to childbearing and thus prefer part-time jobs or jobs where the wage "penalty" for absence from work is low. Based on this argument, we would observe

\footnotetext{
${ }^{2} \mathrm{~A}$ problem which is neglected in many of these studies (i.e. in Bayard et al (1999), Sorensen (1990), le Grand (1991), M iller (1987) and J ohnson and Sol on (1986)) is the fact that the standard errors from OLS estimation are biased since the error term is correlat ed across workers within occupations, see Moulton (1990). It is therefore diф cult to assess the signi..cance of the results in these studies.

${ }^{3}$ Exceptions include Macpherson and Hirsch (1995), Sorensen (1989) and England et al (1988).

${ }^{4} \mathrm{~N}$ ote that this kind of sorting may result from employer discrimination.
} 
a concentration of female workers in these types of jobs, which may al so pay lower wages. It is again clear that the assumption of no correlation between the density of females in an occupation and the error term can be violated. To avoid the potential problem with endogeneity, Macpherson and Hirsch (1995) use longitudinal data covering the period 1983 to 1993 and apply a ..xed-exects estimator. ${ }^{5}$ The advantage with such a procedure is that it differences out any time-invariant unobserved (and observed) variables. Under the assumption that only the time-invariant portion of the error terms are correlated with FE M , this procedure yields unbiased estimates of the exect of $\mathrm{FEM}$ on wages. A serious problem with this approach, however, is the fact that few workers change their occupational status over time and only a small subsample of occupational movers identify the coed cient. Further, the movers may constitute a non-representative portion of the sample, they may for example be younger and clustered in low-skill jobs.

Bearing in mind the potential problems with the usage of panel data in this type of study, we instead suggest the use of a dixerent approach. We aggregate the F E M -variable into three categories depending on the proportion of women in the occupation: male dominated (less than 33 percent females), intermediate (between 33 and 66 percent females) and female dominated (more than 66 percent females). Non-random selection into an occupation is controlled for by estimating an ordered probit model in the ..rst stage and including a selection correction term in the second stage wage equations. ${ }^{6}$ The main advantage with this approach is that it allows us not only to estimate the wage exect of female density in any given occupation, but it al so enables us to estimate the unexplained gender wage gap within a given occupation and how this gap varies across occupations. In addition, we can also test whether the returns to accumulated human capital dixer across both gender and occupations. For example, if most female workers choose occupations where the wage "penalty" for work absence is low, we may expect ‡atter ageearnings pro..les for women in female dominated jobs. The main problems with our approach are ..nding valid instruments for occupational choices and

\footnotetext{
${ }^{5}$ England et al (1988) apply a similar strategy on a sample taken from the National Longitudinal Survey.

${ }^{6} \mathrm{~T}$ his approach is an extension of the approach taken in Sorensen (1989), who rely on a bivariate probit approach. O ur approach allow us to disaggregate the F E M -variable to any desired level, while this is not possible in Sorensen's approach and her results may be sensitive towards this aggregation.
} 
the importance of aggregation. Concerning the ..rst problem, it is in general diф cult to obtain observable characteristics that inłuence occupational choice while at the same time have no impact on wages. In this paper, we use information on the number of children and age as instruments. ${ }^{7}$ The second concern is how sensitive our results are towards the degree of aggregation we pursue. In order to assess this point, we provide estimates from two dixerent speci..cations that dixer only in the number of occupational groups.

Our main results can be summarized as follows. We ..nd that FE M has a signi..cant and negative exect on female wages in Sweden, but only a small and insigni..cant exect on male wages. The negative exect that we ..nd for Swedish females is about half of what Macpherson and Hirsch (1995) found for U.S. data. Hence, the results con..rm the hypothesis that the higher wage equality in Sweden compared to the U.S. implies a lower wage penalty of job femaleness in Sweden than in the U.S. We also found support for the hypothesis that workers self-select themselves into dixerent occupations, as the inclusion of the correction terms for self-selection has a signi..cant impact on the results. We also found evidence of substantial heterogeneity in the gender wage gap. For example, in male dominated occupations, the unexplained wage gap is about 0.018 (and not signi..cant). This is signi..cantly smaller than the estimate (0.121) obtained in femal e dominated occupations. The results also show that the female coec cient for work experience is about 60 percent higher in male dominated occupations compared to female dominated occupations. The experience-earnings pro..les for women in these two occupational groups shows a much steeper earnings pro..le for women in male dominat ed occupations. This result is in line with one of the competing theories explaining occupational segregation, which argues that individuals

\footnotetext{
${ }^{7}$ We expect that number of children is a more valid instrument for women since they are more likely to base their occupational choice on expected number of children than men. This implicitly assumes that there is a strong correlation between expected and actual number of children and that number of children has no impact on wages, conditional upon occupation. We believe that these assumptions are valid. Concerning the use of age as an instrument, we note that, once control for actual work experience is included in the wage equation, there is nothing in human capital theory that predicts age to be a determinant of wages. O veridenti.. cation tests reported in the result section suggests that our choice of instruments appear to be valid. It should also be noted that Sorensen (1989) does not provide a discussion about choice of instruments and her exclusion rest rictions seem quite arbitrary. She relies on job characteristics such as work conditions and type of education required to perform the job.
} 
who expect labor force intermittence will choose occupations in which the penalty for intermittence is lowest. Finally, we showed that ignoring occupational dixerences in labor market may substantially overestimate the unexplained gender wage gap, as much of this dixerences can be explained by wage dixerences across occupations jointly with occupational segregation.

Section 2 of this paper provides a discussion of theories on occupational segregation used in the empirical literature trying to explain occupational segregation and the gender wage gap. Section 3 describes the data and sample used in this study. The empirical speci..cation is presented in Section 4 while the results are presented in section 5. A ..nal section contains a summary of the paper.

\section{Theories on Occupational Segregation}

In the empirical literature there is a general understanding that occupational segregation is present and that females are gathered disproportional in occupations with low earnings. However, there is no agreement on the cause of these outcomes and two contradicted theories have been given in the literature. The .r.st line argues that females are gathered disproportional in occupations with low earnings due to market discrimination and the second line argues that it is due to a self-sorting mechanism.

One theoretical explanation of market discrimination is sometimes referred to as the crowding hypothesis, Bergman (1974). The crowding model states that employer's discriminate against females by excluding them from occupations considered being male jobs. These jobs are reserved for males and few women have the opportunity to get a work in these jobs. Females are crowded into other occupations, referred as female jobs. Wages in these jobs are lower because of an increasing supply of women in the labor market and because there are few female jobs. The model assumes that females and males have the same characteristics and without discrimination they would be paid equally. Thus, because of discrimination males and females are segregated into dixerent occupations. Occupations considered being primarily female occupation pay less than occupations considered being primarily male occupation despite the fact that all workers are quali..ed for both types of occupations. 
The quality sorting hypothesis, Macpherson and Hirsch (1995), is another explanation of market discrimination used in the literature. If females but not males are crowded into low earnings jobs only due to discrimination, then the gender composition of a job becomes an index of labor quality for males and, to a smaller degree, for females. Males who are relatively less productive accept low earnings work in primarily female occupations. Over time, low earnings occupations, crowded by females, would attract relatively less productive males and loose high productive females. Thus, over time we should observe workers with lower productivity and wages in these occupations.

For the non-discriminating line, Polachek ( 1981 and 1985) argue that individuals who expect labor force intermittence will choose occupations in which the penalty for intermittence, atrophy or depreciation of human capital, is lowest. These occupations will have high starting wages and $\ddagger$ at earnings pro..les.

Other explanations for occupational segregation that have appeared in the literature includes among others Becker (1985) who argues that females who expect to spend a lot of time at home choose a job that demands relatively less exort. Other authors, such as Murray and Atkinson (1981), Forgionne and Peters (1982) and Filer (1985), have shown that females have a preference for non-economically working conditions while males thinks more in economic terms.

\section{Data}

The data used in the empirical analysis is drawn from a cross-section of the Swedish Household Income Survey (HINK) complemented with information on occupational segregation taken from the 1996 Labor Force Survey. B oth of these data sources are supplied by Statistics Sweden. HINK provides information on labor market activities and incomes for a random sample of Swedish households, and approximately 7,000 households are interviewed each year. In this paper we use data from the 1997 survey. An interesting feature of this data set is the possibility of matching individual records with wage information provided by employers. The hourly wage rates obtained in this fashion correspond to the workers' contracted wages and do not suxer from the usual measurement errors which are common in self-reported wages. 
The wage information is available for all publicly employed workers as well as for the majority of privately employed workers. ${ }^{8}$

We limit the analysis to individuals aged 18 to 65 and to those individuals who are not self-employed. After these selections we are left with 3,995 females and 3,625 males.

To construct the FEM -variable which measures the proportion of workers who are women in a given occupation, we used information from the Labor Force Survey. In HINK we have information about the individuals' occupation at a two-digit level, and we can distinguish betwen 38 dixerent occupations in the data. ${ }^{9}$ In the second part of the empirical analysis where we estimate models controlling for self-selection into occupations, we split occupations into male dominated, female dominated and integrated following the convention in the literature, see Hakim (1998) and J acobs (1995). Speci...cally, we de. ne occupations with less than 33 percent women as being male dominated occupations and occupations with less than 33 percent men form the female dominated category. The remaining occupations form the integrated occupations category.

Explanatory variables used in the empirical analysis include information on: thehighest educational degre each person has obtained, actual years of work experience, area of living (urban areas, medium-sized cities or the countryside), marital status and hours of work. In addition to these variables, we included information on number of children and age, acting as instruments, in the ordered probit model.

In Table 1 we present descriptive statistics for females and males by occupational type. For women, we observe higher average wage rates in male dominated and intermediate occupations than in female dominated occupations. Despite this, women in the latter occupational group have on average

\footnotetext{
${ }^{8}$ Since wages were not available for all privately employed workers, our sample contains a higher concentration of publicly employed workers than what is observed in the population. To test if our results were sensitive towards this, we estimated models with and without sample weights. We found that there were virtually no dixerence in the re gression estimates and we are therefore con..dent that our results are not driven by the non-represent ative nature of our sample.

${ }^{9}$ Details about type of occupation and the proportion of women in each occupation is provided in Table A 3 in A ppendix.
} 
higher education. We also observe a signi..cant dixerence in the proportion of women working full-time. A mong females in male dominated occupations, 77 percent work full-time (more than 1,500 hours per year). A mong females in female dominated occupations, this ..gure is only 48 percent. It is inter esting to note that this pattern cannot be observed for male workers con..rming the traditional view that male labor supply is less łexible than female labor supply. Finally, we also see from Table 1 that males in female dominated occupations are highly educated as 50 percent has a college/ university degree, compared to only 8 percent in male dominated occupations.

\section{Econometric Speci..cation}

The relationship between wages and gender composition can be estimated by

$$
\begin{aligned}
& \ln w_{i}={ }^{-}{ }^{w} X_{i}+f^{w} F E M_{i}+\left(\dot{A}_{k}^{w}+{ }_{i}{ }_{i}^{w}\right) \quad \text { 8i } 2 w \\
& \ln w_{i}={ }^{-m} X_{i}+f^{m} F E M_{i}+\left(\grave{A}_{k}^{m}+{ }_{i}^{m}\right) \text { 8i } 2 M
\end{aligned}
$$

where $\mathrm{W}$ denotes the set of women in the sample and $\mathrm{M}$ denotes the set of men. Further, $\mathrm{i}=1 ; \ldots ; ; \mathrm{N}^{\mathrm{w}}$ for women and $\mathrm{i}=1 ; \ldots ; ; \mathrm{N}^{\mathrm{m}}$ for men. Subindex $\mathrm{i}$ denotes individuals and subindex $\mathrm{k}$ denotes occupations. The last two terms of the above relationships concerns the error structure of the model. Unobserved occupational-speci..c exects are assumed to be captured in $\grave{A}_{k}$, while " $;$ is an individual-speci..c disturbance term, rełecting exects of unobservable variables that vary across individuals. It is assumed that: (1) the sequence $\left\{{ }{ }_{i}\right\}$ consists of normal i.i.d. random variables with mean zero and a constant variance 3/4; (2) $\dot{A}_{k}$ is normally distributed with mean zero and a homoscedastic variance 3/2: Further, $\ln w_{i}$ is the natural log of hourly earnings for individual $\mathrm{i}$ and $\mathrm{X}_{i}$ includes controls for highest education attained, work experience, marital status, area of living and labor supply; $F E M_{i}$ is the concentration of women in worker i's occupation. A s argued by $M$ oulton (1990), Macpherson and Hirsch (1995) and B aker and Fortin (1999), estimating the above equations with OLS yields biased standard errors since a part of the error term $\left(\grave{A}_{k}\right)$ is correlated across workers within occupations. To obtain correct standard errors we apply a random exects estimator to the model in equations (1a) and (1b). 
However, as was argued in the introduction, there exists plausible reasons for assuming that FEM is endogenously determined. If this is the case, the estimates from equations (1a) and (1b) are not valid. The approach that we adopt in this paper, which controls for this type of potential misspeci..cation, is to estimate a version of Heckman's two-step estimator. In the ..rst stage, we estimate an ordered probit model that determines the probability of choosing a speci..c type of occupation (that is, male dominated, female dominated or an intermediate occupation). The parameters from the ordered probit are then used to form a selection correction term (similar to Heckman's lambda) that is added to the regression equation in the second stage. Formally, the model can be speci..ed as follows:

$$
\begin{aligned}
& F E M_{i j}^{\alpha}={ }^{0} Z_{i j}+{ }^{\prime}{ }_{i j} \\
& F E M_{i j}=k \text { if }{ }^{1} k_{i 1}<F E M_{i j}^{x} \cdot{ }^{1} k_{i} \\
& \text { where } \mathrm{k}=0 ; 1 ; 2 \text { and }{ }^{1}{ }_{\mathrm{k}_{\mathrm{i}} 1}<{ }^{1}{ }_{\mathrm{k}} \text { : }
\end{aligned}
$$

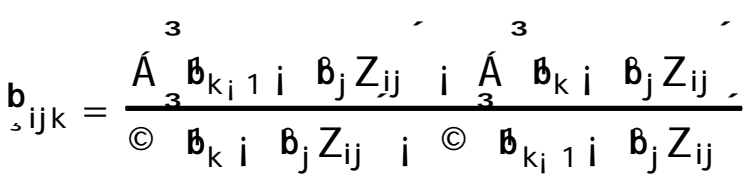

$$
\begin{aligned}
& \ln w_{i j k}={ }^{-}{ }_{j k} X_{i j k}+@_{k} b_{i j k}+{ }^{n i j k} \\
& \text { "ij k i:i :d: N }(0,3 / 2) \\
& { }_{i j} \sim \mathrm{i}: \mathrm{i}: \mathrm{d}: \mathrm{N}(0,1)
\end{aligned}
$$

where subindex $\mathrm{j}$ denotes gender $(\mathrm{j}=\mathrm{w}$ or $\mathrm{m})$. Further, $\mathrm{A}$ and $\odot$ are the standard normal probability density function and distribution function, respectively. The ${ }^{1}$ 's are unknown parameters to be estimated jointly with ${ }^{\circ}$; and refect threshold values for moving through the occupational choice decision. It is further assumed that " ${ }_{i j k}$ and ' ${ }_{i j}$ are correlated with correlation coec cient $1 / 2$ A sis the case in a standard $\mathrm{H}$ eckman model, thestandard errors of the estimates equation (2) needs to be adjusted. 


\section{Empirical Results}

This section is divided into two subsections. In the ..rst, we present results based on equations (1a) and (1b) above. In the second subsection, we present results based on equation (2), which are corrected for self-selection.

\subsection{Results without controlling for self-selection}

The results from estimation of equations (1a) and (1b) above are presented in Table 2. In the ..rst column we present estimates of the exect of FE M on male and female wages without including any other controls. The results show a negative but not signi..cant exect of $F E M$ on female wages $(-0.102)$ and a positive exect on male wages $(0.061)$. The results for males can to a certain extent be explained by the fact that males in female dominated occupations have on average much higher education than males in male dominated occupations (see Table 1). For females, there is a negative exect, despite the fact that female workers in female dominated occupations also have higher education. O ne likely explanation for the negative exect however is the fact that 77 percent of women in male dominated occupations work full-time while this ..gure is only 48 percent in female occupations. A larger negative exect of FE M on wages for females than for males was also found in Macpherson and Hirsh (1995). ${ }^{10}$

In column two of Table 2 we rep ort estimates of a version of equations (1a) and (1b) above when we include controls for observable individual characteristics. When we add these controls, the negative exect on female wages drop to -0.091 , but it is now signi..cant (the $p$-value equals 0.076 ). For males, the coeł cient is also negative, -0.013 , but not signi..cantly dixerent from zero. These results indicates that the negative exect on wages from female concentration in occupations, which has been shown to exist in the U.S., also exists in Sweden but the exect is smaller. ${ }^{11}$ As was argued earlier, this is an expected result, in part due to the compressed Swedish wage distribution.

\footnotetext{
${ }^{10}$ Their estimates (without any controls) were -0.2305 and -0.0375 for females and males, respectively.

${ }^{11} \mathrm{M}$ acpherson and $\mathrm{H}$ irsh (1995) report that the exect in their "base" speci..cation, which is the one most similar to ours, is -0.172 for females and -0.139 for males (Table 5, page 445).
} 


\subsection{Results with controls for self-selection}

In Table 3 we present results from the ordered probit. The entries in the ..rst two columns refer to the results for males, while the last two columns show results for females. The results show that education and occupational choice is strongly correlated and that the probability of working in a female dominated occupation is higher for those with higher education. This results holds for both males and females. As expected, the exect of work experience is the opposite of that of education. However, it is only signi..cant for males. Males living in urban areas (i.e. Stockholm, Göteborg or Malmö) have a higher probability of working in female dominated occupations than other men. For women, we observe the opposite, namely that women who lives in urban areas are more likely to work in male dominated occupations. This suggests that occupational segregation is more signi..cant in the countryside, perhaps because (occupational) traditions are more important there than in larger cities. Marital status does not have any signi..cant impact on either male or female occupational choice. Finally, we note that labor supply has no impact on occupational choice among men, but a signi..cant exect on females' choices. The negative coeł cient implies that women who work full-time are more likely to work in a male dominated occupation.

Regarding the exects of the instruments on occupational choice, we see that number of children has a negative exect for males and a positive exect for femal es. The estimate for males has a p-value of ab out 0.13 , and implies that, everything else held constant, males with many children are more likely to hold a job in a male dominated occupation. For females, the estimate in column three implies the opposite, namely that females with many children are more likely to hold a job in a female dominated occupation. T hese results are not surprising. For instance, assuming that the age-earnings pro..le for women is ₹atter in female dominated occupations, the wage penal ty of work absence is lower in these jobs. We would then expect women with many children (and therefore with more work absence) to prefer these types of jobs rather than jobs where the wage penalty is bigger (as in male dominated jobs). As a second instrument we include age. The reason for including this variable is the assumption that occupational segregation is more pronounced among older cohorts than among younger ones. This is also con..rmed in Table 3, which shows that men and women from older cohorts are more likely to possess jobs in segregated occupations. In the very last portion of 
Table3, we report values of likelihood-ratio tests, which clearly reject thenull hypothesis that the instruments have no signi..cant impact on occupational choice.

Table 4 contains the wage estimates for females. The results in the ..rst two columns refer to male dominated occupations, while columns three and four show the results for integrated occupations and the last two columns show estimates for females working in female dominated occupations. For all categories, the estimates regarding highest educational attainment (i.e. high-school degree or a college/ university degree) are all insigni..cant. This suggests that, everything else equal, wages among women with a high-school degree (or a college degree) are not signi..cantly dixerent from wages among women with less schooling.

One of the competing theories explaining occupational segregation argues that individuals who expect labor force intermittence will choose occupations in which the penalty for intermittence is lowest (see for instance Polachek (1981 and 1985)). These occupations will have high starting wages and $\ddagger$ at earnings pro...es. An implication of this theory is that women (who expect more frequent labor force intermittence) choose female dominated occupations because the penalty for intermittence is lower in these occupations than in male dominated occupations. Whether the earnings pro..les are indeed fatter in female dominated occupations is an empirical matter. The results in Table 4 lends some support for this hypothesis since the coet cient for work experience is about 60 percent higher in male dominated occupations compared to female dominated occupations. The experience-earnings pro..les for women in these two occupational groups are shown in Figure 1, which clearly shows a much steeper earnings pro..le for women in male dominated occupations.

Concerning the remaining covariates in the wage equations, we ..nd that women in urban areas (Stockholm, Göteborg and Malmö) have on average higher wages. There is a signi..cant wage premium to marriage and of working full-time for women in integrated occupations. Finally, the selection correction variable, lambda, is not signi..cant suggesting no support for the hyp othesis that women self-sel ect themselves into dixerent occupations. Hence, we cannot reject the hypothesis that women are randomly allocated into diperent occupations. 
Table 5 contains the wage estimates for males. 0 verall, most of the results are in accordance with our prior expectations. The results regarding the effects of human capital imply higher return to education in male dominated occupations and higher return to work experience in female dominated occupations. Further, there is a signi..cant, negative wage ex ect of being single in integrated occupations and a signi..cant, positive exect of working full-time. However, contrary to the results for females, we ..nd that the selection correction variable is signi...cant, suggesting that men self-select themselves into dixerent occupations.

To test whether our choice of instruments is valid, we report the $p$-values for these variables when they were included in the wage equation. To achieve identi..cation (without relying on the non-linear nature of the model), we included them separately. For women, the $p$-values for age strongly suggest that age can serve as an instrument. However, regarding number of children, the $p$-values are high in both male dominated and female dominated occupations, but not so in intermediate occupations (where the $p$-value equals 0.039). This may suggest that part of our identi..cation does not rely on a proper set of instruments. Perhaps as a consequence of poor instruments, none of the selection correction terms are signi..cant for females and our results are not sensitive to the inclusion of these terms. For males however, both age and number of children appear to be valid instruments.

The entries in Table 6 shows observed, explained and unexplained (log) wage gaps across occupations and gender. The ..rst two rows show the dixerence in log-wages for females in male dominated versus female dominated occupations. The observed dixerence is 7.3 percent. However, as shown in the second col umn, the explained gap is negative, -0.057 . This means that women in female dominated occupations have, on average, more accumulated human capital and that, based on this, the wage gap should be negative. This also means that the part of the wage dixerence that is unexplained is larger than the observed one. The unexplained gap is estimated to equal 0.131 , implying a wage penalty of working in female dominated occupations for women of about 13 percent.

The ..gures for male workers are presented in the second set of rows in Table 6. As was shown in Table 1, male wages are higher in female occupations compared to mal eoccupations, mostly due to dixerences in educational levels 
between the two groups. This is also shown in Table 6, which states that a large fraction (about 85 percent) of the observed wage dixerence can be explained by dixerences in observable characteristics.

In the last set of results in Table 6, we present observed, explained and unexplained gender wage dixerentials in the three occupational groups. The observed gender wage gap is smallest (2.6 percent) in male dominated occupations and largest in female dominated occupations (16.7 percent). As is shown in the last col umn, most of the observed wage dixerence is attributed to unobserved factors (of which labor market discrimination may be one). In both male and female dominated occupations, about 30 percent of the observed wage gap can be "explained" by dixerences in observable characteristics (such as accumulated human capital and labor supply) and about 70 percent remains unexplained. It is interesting to observe that there exists substantial heterogeneity in the gender wage dixerentials across occupational groups. This is an observation that, surprisingly, has received little attention in the literature. A nother interesting implication of our results on the gender wage gap is that the unexplained portion of this gap is not smallest in occupations with an equal gender distribution. This would suggest that policies such as aф rmative action would have only limited exect on the unexplained wage gap.

\subsection{Decomposing the gender wage gap}

U sing our approach to estimate the gender wage gap enables us to decompose this gap into three mutually exclusive parts: dixerences in endowments, differences in occupational structure and dixerences in rewards to endowments. Formally, this can be written as:

$$
\begin{aligned}
& \overline{\ln w_{m}} i \overline{\ln w_{w}}=x \quad 1 / 4 m\left(\overline{Z_{i}^{m}} i \overline{Z_{i}^{w}}\right) \not b^{m}+ \\
& \mathrm{i}^{2 \mathrm{~J}} \\
& x^{2 j} \\
& \text { i2) } \\
& \left(1 / 4^{m} i \frac{1 / 4}{w}\right) \times \overline{Z_{i}^{w}} a^{b^{w}}+ \\
& 1 / 4 a \overline{Z_{i}^{w}} a\left(b^{m} i b^{w}\right)
\end{aligned}
$$

where the .r.st term on the right hand side measures dixerences in endowments $\left(\overline{Z_{i}^{m}} i \overline{Z_{i}^{\mathrm{w}}}\right)$, the second measures dixerences in occupational structure 
$\left(1 / 4{ }^{1 / N}\right)$ and the last one measures the gap due to unexplained factors $\left(b^{\mathrm{m}} i b^{\mathrm{w}}\right)$. The $1 / 4^{\prime} \mathrm{s}$ are proportions of workers (men or women) in occupation $\mathrm{i}$, and there is a total of J dixerent occupations.

The results of this decomposition is reported in Table 7 for four dixerent speci..cations. In the ..rst column, we show the results from a model (estimated by OLS) which does not allow occupational structure to axect wages. In this case, 30 percent of the observed (log) wage gap between men and women can be explained by dixerences in endowents (primarily education and experience) and 70 percent of the gap is left unexplained and in much previous work, this is attributed to labor market discrimination. In coulmn two, we show how false that conclusion is. The entries in this column are obtained by estimating separate wage regressions for three occupational groups. The results from this shows that the gap which is due to unexplained factors drop substantially, from 70 percent to ab out 40 percent. We can further infer from the results that about 40 percent of what was earlier attributed to unexplained factors (discrimination) is simply due to dixerences in occupational structure. ${ }^{12}$ Hence, it is important to control for occupational dixerences when making inference about the gender wage gap, and neglecting to do so might yield overestimated unexplained wage gaps. Columns three and four shows results when non-random selection into occupations are controlled for and they show a simlar picture as the results in column two.

\subsection{R obustness of the results}

In an attempt to explore the robustness of our results towards the assumption of aggregation of the FEM -variable we have estimated a model in which we aggregated the FE M -variable into four groups instead of three ${ }^{13}$ The results from this sensitivity analysis are found in Table A 2 in appendix. It would al so have been interesting to test how sensitive our results are towards dixerent assumptions regarding the set of instruments. However, due to

\footnotetext{
${ }^{12} \mathrm{~N}$ ote however that part of the occupational structure may be the outcome of a discriminat ory process.

${ }^{13}$ Speci..cally, we de..ne occupations with less than 25 percent women as being male dominated occupations and occupations with less than 25 percent men form the female dominated category. The remaining occupations form two "semi-integrated" occupations, one consisting of occupations with 25-50 percent men and one consisting of 25-50 percent women.
} 
limited information on individual, observable characteristics included in the data, we are unfortunately restricted in our ability to rigorously test these assumptions.

In Table A2 we present observed, explained and unexplained (log) wage gaps across occupations and gender. The entries in this table should be compared to the ones in Table 6 . We ..nd a larger wage gap between male and female dominated occupations for women. Given the construction of the groups, this is not surprising. For males, we ..nd a smaller observed wage gap between male and female dominated occupations, but the unexplained gap is similar to that reported in Table 6. Regarding the gender pay gap, the entries in Table A 2 show the same pattern as in Table 6. The wage gap is smallest in male dominated occupations and largest in female dominated occupations. Overall, the results in Table A 2 are of similar magnitudes as the ones in Table 6 suggesting that our results in Table 6 are robust towards aggregation of the F E M -variable.

\section{Conclusions}

The purpose of this paper has been to study if there exists any wage penalty for working in occupations which are characterized by a high concentration of femal e workers in Sweden. The negative exect for women is however lower than what has been reported for the U.S., a result which is expected given the high degree of wage equality in Sweden compared to the U.S. We have also extended previous work in this area by estimating a framework that accounts for workers self-selection into dixerent occupations. The inclusion of correction terms for self-selection was shown to have a signi..cant impact on the results. Within this framework, we found that the unexplained wage gap for females between male and female jobs is about 13 percent. For males, we found evidence of a small and insigni..cant gap.

Our results also showed that the female coet cient for work experience is about 60 percent higher in male dominated occupations compared to female dominated occupations. The experience earnings pro..les for women in these two occupational groups shows a much steeper earnings pro.l.e for women in male dominat ed occupations. This result is in line with one of the competing theories explaining occupational segregation, which argues that individuals 
who expect labor force intermittence will choose occupations in which the penal ty for intermittence is lowest.

Finally, we used our model to investigate how the gender wage gap dixers across occupational groups, and found strong indications of a small and insigni..cant (2.6 percent) gender wage gap in male dominated occupations and a signi..cant gap (16.7 percent) in female dominated occupations. M ost of the observed wage dixerence across all occupational groups is attributed to unobserved factors (of which labor market discrimination may be one). In both male and female dominated occupations, about 30 percent of the observed wage gap can be "explained" by dixerences in observable characteristics (such as accumulated human capital and labor supply) and about 70 percent remains unexplained. The heterogeneity in the gender wage differentials across occupational groups which we ..nd support for in this paper suggests that at rmative action policies will only have limited exect on the unexplained wage gap. 


\section{R eferences}

[1] Baker, M. and Fortin, N.M. (1999) "Occupational Gender Composition and Wages in Canada:1987-1988," NBER working paper 7371.

[2] Bayard, L., J. Hellerstein, D. Neumark and K. Troske (1999) "New Evidence on Sex Segregation and Sex Dixerences in Wages from M atched Employee-Employer Data," NBER working paper 7003.

[3] Becker, G. (1985) "Human Capital, Exort and the Sexual Division of Labor," J ournal of Labor Economics, 3(1), 33-58.

[4] Bergman, B. R. (1974) "Occupational Segregation, Wages and Profits When Employer Discriminate by Race and Sex," Eastern Economic J ournal, 1, 103-10.

[5] Blau, F.D. and K ahn, L.M. (1992) "T he Gender E arnings Gap: Learning from International Comparisons," American Economic Review, 80(2), 533-539.

[6] Blau, F.D. and Kahn, L.M. (1996) "The Gender Earnings Gap: Some Internati onal Evidence," In Richard B. Freeman and Lawrence F. K atz, eds., Dixerences and Changes in Wage Structures, Chicago and London, The University of Chicago Press, pp. 105-145.

[7] Dickens, W.T. and Lang, K. (1985) "A Test of Dual Labor Market Theory," American E conomic Review, 75(4), 792-805.

[8] England, P., G. Farkas, B.S. Kilbourne and T. Dou, (1988) "Explaining Occupational Sex Segregation and Wages: Findings from a Model with Fixed Exects," American Sociological Review, 53, 544-558.

[9] Filer, R. K. (1985) "Male-Female Wage Dixerences: The Importance of Compensating Dixerentials," Industrial and Labor Relations Review, 38(3), 426-37.

[10] Forgionne, G. and Peters E. E. (1982) "Dixerences in J ob M otivation and Satisfaction A mong Maleand Female Managers," Human Relations, 35(2), 101-118.

[11] Hakim, C. (1998), Social Change and Innovations in the Labour Market, Oxford UK : Oxford University P ress 
[12] J acobs, S.C. (1995) "Changing Patterns of Sex Segregated Occupations Throughout the Lifecourse," European Sociological Review, 11(2), 15771

[13] J ohnson, G. and G. Solon (1986) "Estimates of the Direct Exects of Comparable Worth Policy," A merican Economic Review, 76(5), 111725.

[14] le G rand, C. (1991) "Explaining the M ale-Female Wage Gap: J ob Segregation and Solidarity Wage Bargaining in Sweden," Acta Sociologica, 34, 261-278.

[15] Macpherson, D. A. and B. T . H irsch (1995) "Wages and Gender Composition: W hy Do Women's J obs Pay Less?," J ournal of Labor Economics, 13, 426-71.

[16] Miller, P. W . (1987) "T he Wage E xect of the Occupational Segregation of Women in Britain," Economic J ournal, 97, 885-896.

[17] Moulton, Brent R. (1990) "An Illustration of a Pitfall in Estimating the Exects of A ggregate Variables on Micro Units," Review of Economics and Statistics, 72, 334-338.

[18] Murray, M. A . and Atkinson J . (1981) "Gender Dixerences in the Correlates of J ob Satisfaction," Canadian J ournal of Behavioral Science, $13(1), 44-52$.

[19] Polachek, S. W . (1981) "Occupational Self-Selection: A Human Capital A pproach to Sex Dixerences in the O ccupational Structure," Review of Economics and Statistics, 63(1), 60-69.

[20] Polachek, S. W. (1985) " Occupational Segregation: A Defense of Human Capital Predictions," J ournal of Human Resources, 20(3), 437-40.

[21] Sorensen, E. (1990) " The Crowding Hypothesis and Comparable Worth Issue: A Survey and New Results," J ournal of Human Resources, 25, 55-89.

[22] Sorensen, E. (1989) " M easuring the Pay Disparity Between Typically Female $O$ ccupations and Other J obs: A Bivariate Selectivity A pproach," Industrial and Labor Relations Review, 42(4), 624-639. 


\section{Table 1. Descriptive Statistics by Occupational Type.}

\begin{tabular}{|c|c|c|c|c|c|c|}
\hline \multirow[b]{2}{*}{ Characteristics } & \multicolumn{2}{|c|}{$\begin{array}{c}\text { Male Dominated } \\
\text { Occupation }\end{array}$} & \multicolumn{2}{|c|}{$\begin{array}{l}\text { Intermediate } \\
\text { Occupation }\end{array}$} & \multicolumn{2}{|c|}{$\begin{array}{c}\text { Female Dominated } \\
\text { Occupation }\end{array}$} \\
\hline & M ean & Std & M ean & Std & Mean & Std \\
\hline Wage per hour (1997 SE K) & 107.7 & 28.4 & 106.1 & 31.6 & 99.3 & 22.2 \\
\hline High-School & 0.53 & - & 0.60 & - & 0.67 & - \\
\hline College/University & 0.13 & - & 0.16 & - & 0.20 & - \\
\hline Work experience & 18.9 & 10.1 & 21.3 & 10.6 & 20.4 & 10.1 \\
\hline Living in urban areas & 0.31 & - & 0.39 & - & 0.29 & - \\
\hline $\begin{array}{l}\text { Living in medium- } \\
\text { sized cities }\end{array}$ & 0.37 & - & 0.37 & - & 0.39 & - \\
\hline Prop. single & 0.18 & - & 0.15 & - & 0.15 & - \\
\hline Prop. working full-time & 0.77 & - & 0.67 & - & 0.48 & - \\
\hline Number of children & 0.8 & 1.0 & 0.7 & 1.0 & 0.9 & 1.1 \\
\hline Age & 40.3 & 10.7 & 43.1 & 10.8 & 42.5 & 10.8 \\
\hline \multirow[t]{3}{*}{ Number of observations } & \multicolumn{2}{|c|}{332} & \multicolumn{2}{|c|}{1650} & \multicolumn{2}{|c|}{2013} \\
\hline & \multicolumn{6}{|c|}{ Men } \\
\hline & \multicolumn{2}{|c|}{$\begin{array}{c}\text { Male Dominated } \\
\text { Occupation }\end{array}$} & \multicolumn{2}{|c|}{$\begin{array}{l}\text { Intermediate } \\
\text { Occupation }\end{array}$} & \multicolumn{2}{|c|}{$\begin{array}{c}\text { Female Dominated } \\
\text { Occupation }\end{array}$} \\
\hline Characteristics & M ean & Std & M ean & Std & Mean & Std \\
\hline "Wage per hour (1997 SEK ) & 111.0 & 32.2 & 124.8 & 499.2 & 121.5 & 46.9 \\
\hline High-School & 0.65 & - & 0.58 & - & 0.42 & - \\
\hline College/ University & 0.08 & - & 0.24 & - & 0.50 & - \\
\hline Work experience & 23.2 & 12.2 & 22.5 & 11.9 & 21.1 & 11.3 \\
\hline Living in urban areas & 0.27 & - & 0.43 & - & 0.34 & - \\
\hline $\begin{array}{l}\text { Living in medium- } \\
\text { sized cities }\end{array}$ & 0.41 & - & 0.37 & - & 0.40 & - \\
\hline Prop. single & 0.14 & - & 0.13 & - & 0.19 & - \\
\hline Prop. working full-time & 0.76 & - & 0.82 & - & 0.78 & - \\
\hline Number of children & 0.8 & 1.1 & 0.8 & 1.0 & 0.8 & 1.0 \\
\hline Age & 41.8 & 11.0 & 42.8 & 10.8 & 43.1 & 11.1 \\
\hline
\end{tabular}




\section{Table 2. The E xect of Occupational Segregation on Wages.}

\begin{tabular}{lcccc} 
& \multicolumn{2}{c}{ Speci..cation 1 } & \multicolumn{2}{c}{ Speci..cation 2 } \\
Variable & Est. & Std.err. & Est. & Std.err. \\
\hline \hline Female densitity in occupation & -0.102 & 0.078 & -0.091 & 0.051 \\
$\begin{array}{l}\text { Male indicator interacted with } \\
\text { female densitity in occupation }\end{array}$ & 0.163 & 0.029 & 0.078 & 0.027 \\
Male & & & & \\
\hline \hline
\end{tabular}

Notes: Speci..cation 1 includes no controls for observable characteristics. Speci..cation 2 includes controls for education, work experience, area of living, marital status and labor supply. All these controls are interacted with the Male indicator. 


\section{Table 3. Ordered Probit Estimates.}

\begin{tabular}{l|cc|cc}
\multirow{2}{*}{ Variable } & \multicolumn{2}{|c|}{ Males } & \multicolumn{2}{c}{ Females } \\
\hline Constant & Est. & Std.err. & Est. & Std.err. \\
High-School & -1.548 & 0.159 & 1.131 & 0.123 \\
College/ University & 0.215 & 0.053 & 0.506 & 0.048 \\
Experience & 0.919 & 0.072 & 0.686 & 0.063 \\
Experience ${ }^{2}$ / 100 & -0.040 & 0.009 & -0.003 & 0.009 \\
Living in urban areas & -0.005 & 0.015 & 0.002 & 0.017 \\
Living in medium- & 0.048 & 0.053 & -0.142 & 0.048 \\
sized cities & & & & 0.051 \\
Single & -0.071 & 0.062 & 0.014 & \\
Working full time & -0.033 & 0.050 & -0.536 & 0.053 \\
Number of children & -0.033 & 0.022 & 0.050 & 0.040 \\
A ge & 0.047 & 0.006 & 0.006 & 0.021 \\
\hline 1 1 & 1.165 & 0.030 & 1.459 & 0.004 \\
\hline \hline N & \multicolumn{2}{|c|}{3,625} & & 0.031 \\
A ve. Log-Likelihood & 0.8576 & & 0.8730 \\
LR -test ${ }^{1}$ & $63.0(0.0001)$ & & $6.8(0.033)$ \\
\hline Notes: Thedependent
\end{tabular}

Notes: The dependent variable takes on three values: 0 if male dominated occupation, 1 if intermediate and 2 if female dominated.

LR -test $^{1}$ : value of the LR-statistic when testing the instruments in the selection equation, $p$-value in parenthesis (truncated for males). 


\section{Table 4. Wage Equation Estimates for Females, by Occupation.}

\begin{tabular}{|c|c|c|c|c|c|c|}
\hline \multirow[b]{2}{*}{ Variable } & \multicolumn{2}{|c|}{ M ale dominated } & \multicolumn{2}{|c|}{ Intermediate } & \multicolumn{2}{|c|}{ Female dominatec } \\
\hline & Est. & Std. err. & Est. & Std.err. & Est. & Std.err. \\
\hline$\overline{\text { Constant }}$ & 4.737 & 0.737 & 4.170 & 0.160 & 4.650 & 0.298 \\
\hline High-School & 0.082 & 0.172 & -0.086 & 0.133 & -0.042 & 0.107 \\
\hline College/University & 0.339 & 0.245 & 0.071 & 0.187 & 0.109 & 0.146 \\
\hline Experience & 0.015 & 0.007 & 0.009 & 0.005 & 0.009 & 0.004 \\
\hline Experience $^{2} / 100$ & -0.027 & 0.016 & -0.016 & 0.010 & -0.015 & 0.009 \\
\hline Living in urban areas & 0.101 & 0.065 & 0.133 & 0.049 & 0.054 & 0.039 \\
\hline $\begin{array}{l}\text { Living in medium- } \\
\text { sized cities }\end{array}$ & 0.040 & 0.041 & 0.012 & 0.033 & 0.010 & 0.025 \\
\hline Single & -0.097 & 0.045 & -0.048 & 0.034 & -0.027 & 0.029 \\
\hline Working full time & -0.048 & 0.193 & 0.280 & 0.146 & 0.138 & 0.110 \\
\hline Lambda & 0.178 & 0.412 & -0.313 & 0.308 & -0.350 & 0.322 \\
\hline Adj. $R^{2}$ & & 220 & & 269 & & 0.273 \\
\hline$S_{n}$ & & 257 & & 353 & & 0.326 \\
\hline $\begin{array}{l}\text { P-value for number } \\
\text { of children }{ }^{\text {a }}\end{array}$ & & 946 & & 039 & & 0.874 \\
\hline P-value for age ${ }^{b}$ & & 972 & & 347 & & 0.646 \\
\hline
\end{tabular}




\section{Table 5. Wage Equation Estimates for Males, by Occupation.}

\begin{tabular}{|c|c|c|c|c|c|c|}
\hline \multirow[b]{2}{*}{ Variable } & \multicolumn{2}{|c|}{ M ale dominated } & \multicolumn{2}{|c|}{ Intermediate } & \multicolumn{2}{|c|}{ Femal e dominatec } \\
\hline & Est. & Std. err. & Est. & Std.err. & Est. & Std.err \\
\hline$\overline{\text { Constant }}$ & 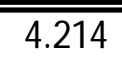 & 0.063 & $\overline{4.532}$ & 0.132 & 4.882 & 0.391 \\
\hline High-School & 0.038 & 0.025 & 0.014 & 0.046 & -0.013 & 0.096 \\
\hline College/University & 0.163 & 0.084 & 0.011 & 0.117 & 0.061 & 0.185 \\
\hline Experience & 0.010 & 0.003 & 0.016 & 0.005 & 0.015 & 0.007 \\
\hline Experience $^{2} / 100$ & -0.015 & 0.006 & -0.025 & 0.010 & -0.020 & 0.016 \\
\hline Living in urban areas & 0.013 & 0.026 & 0.061 & 0.044 & 0.012 & 0.063 \\
\hline $\begin{array}{l}\text { Living in medium- } \\
\text { sized cities }\end{array}$ & 0.020 & 0.022 & 0.007 & 0.041 & -0.016 & 0.055 \\
\hline Single & -0.009 & 0.028 & -0.092 & 0.046 & -0.071 & 0.060 \\
\hline Working full time & 0.136 & 0.022 & 0.231 & 0.039 & 0.090 & 0.056 \\
\hline Lambda & -0.294 & 0.104 & -0.288 & 0.106 & -0.275 & 0.170 \\
\hline Adj. $R^{2}$ & & 265 & & 279 & & 0.387 \\
\hline$S_{n}$ & & 320 & & 388 & & 0.354 \\
\hline $\begin{array}{l}\text { P-value for number } \\
\text { of children }{ }^{\text {a }}\end{array}$ & & 531 & & 579 & & 0.540 \\
\hline P-value for age ${ }^{b}$ & & 181 & & 308 & & 0.587 \\
\hline
\end{tabular}




\section{Table 6. Observed, Explained and Unexplained (log) Wage Gaps.}

\begin{tabular}{l|c|c|c} 
Variable & $\begin{array}{c}\text { O bserved } \\
\text { Gap }\end{array}$ & $\begin{array}{c}\text { Explained } \\
\text { Gap }\end{array}$ & $\begin{array}{c}\text { Unexplained } \\
\text { Gap }\end{array}$ \\
\hline \hline Females: & & & \\
M ale vs Female Dominated & 0.073 & -0.057 & 0.131 \\
& $(0.013)$ & $(0.058)$ & $(0.061)$ \\
& & & \\
M ales: & -0.068 & -0.058 & -0.011 \\
M ale vs Female Dominated & $(0.016)$ & $(0.066)$ & $(0.070)$ \\
& & & \\
M ale-Female Wage Gaps: & & & \\
M ale Dominated & 0.026 & 0.008 & 0.018 \\
Intermediate & $(0.013)$ & $(0.016)$ & $(0.025)$ \\
& 0.136 & 0.037 & 0.099 \\
Female Dominated & $(0.011)$ & $(0.013)$ & $(0.023)$ \\
& 0.167 & 0.047 & 0.121 \\
& $(0.016)$ & $(0.013)$ & $(0.023)$ \\
\hline
\end{tabular}

Note: Standard errors are reported in brackets.

The explained wage gap is calculated as: $\left(\boldsymbol{x}_{m d} i \bar{x}_{f d}\right)_{f d}{ }_{f d}$ where

$\mathbf{X}_{\mathrm{md}}$ equals average characteristics in male dominated occupations, and $\mathbf{X}_{\mathrm{f}} \mathrm{d}$ equals average characteristics in male dominated occupations. 


\section{Table 7. Decomposing the Gender (log) Wage Gap.}

\begin{tabular}{lcccc} 
& & & $\begin{array}{c}\text { Selection } \\
\text { Corrected }\end{array}$ & $\begin{array}{c}\text { Selection } \\
\text { Corrected } \\
\text { (3 groups) }\end{array}$ \\
\hline \hline (4 groups)
\end{tabular}

$\mathrm{OLS}^{1}$ : Includes no control for occupational segregation.

$\mathrm{OLS}^{2}$ : Includes control for occupational segregation. 


\section{A ppendix A:}

\section{Table A 1. Observed, Explained and Unexplained (log) Wage Gaps (OLS).}

\begin{tabular}{l|c|c|c} 
Variable & $\begin{array}{c}\text { Observed } \\
\text { Gap }\end{array}$ & $\begin{array}{c}\text { Explained } \\
\text { Gap }\end{array}$ & $\begin{array}{c}\text { Unexplained } \\
\text { Gap }\end{array}$ \\
Females: & & & \\
M ale vs Female Dominated & 0.073 & -0.015 & 0.089 \\
& $(0.013)$ & $(0.003)$ & $(0.012)$ \\
M ales: & & & \\
M ale vs Female Dominated & -0.068 & -0.139 & 0.071 \\
& $(0.016)$ & $(0.013)$ & $(0.019)$ \\
M ale-Female Wage Gaps: & & & \\
M ale Dominated & 0.026 & 0.002 & 0.024 \\
Intermediate & $(0.013)$ & $(0.008)$ & $(0.014)$ \\
& 0.136 & 0.056 & 0.080 \\
Female Dominated & $(0.011)$ & $(0.002)$ & $(0.010$ \\
& 0.167 & 0.111 & 0.056 \\
\hline \hline
\end{tabular}

Note: Standard errors are reported in brackets.

The explained wage gap is calculated as: $\left(\bar{x}_{\text {md }} i \bar{x}_{f d}\right){ }_{f d}$ where $\bar{x}_{\text {md }}$ equals average characteristics in male dominated occupations, and $\bar{x}_{f d}$ equals average characteristics in male dominated occupations. 


\section{Table A2. Observed, Explained and Unexplained (log) Wage Gaps.}

\begin{tabular}{l|c|c|c} 
Variable & $\begin{array}{c}\text { Observed } \\
\text { Gap }\end{array}$ & $\begin{array}{c}\text { Explained } \\
\text { Gap }\end{array}$ & $\begin{array}{c}\text { Unexplained } \\
\text { Gap }\end{array}$ \\
\hline \hline $\begin{array}{l}\text { Females: } \\
\text { Male vs Female D ominated }\end{array}$ & 0.122(0.017) & $-0.064(0.095)$ & $0.186(0.103)$ \\
M ales: & & & \\
Male vs Female D ominated & $-0.020(0.030)$ & $-0.005(0.107)$ & $-0.015(0.122)$ \\
M al e-Female wage gaps: & & & \\
$\begin{array}{l}\text { Male Dominated (0-25\% women) } \\
\text { Intermediate I (25-50\% women) }\end{array}$ & $0.005(0.017)$ & $0.012(0.023)$ & $-0.007(0.047)$ \\
Intermediate II (50-75\% women) & $0.123(0.015)$ & $0.012(0.023)$ & $0.111(0.037)$ \\
Female Dominated (75-100\% women) & $0.147(0.011)$ & $0.036(0.017)$ & $0.074(0.023)$ \\
\hline
\end{tabular}

Note: These ..gures are estimates based on a model with FEM divided into four dixerent groups. The explained wage gap is calculated as: $\left(\boldsymbol{X}_{m d} i \bar{x}_{f d}\right)^{b}{ }_{m d}$ $\bar{x}_{\mathrm{md}}$ equals average characteristics in male dominated occupations, and $\mathbf{x}_{\mathrm{fd}}$ equals average characteristics in male dominated occupations 


\section{Table A3. Occupational Speci..cation and Proportion of Women in each Occupation.}

\begin{tabular}{|c|c|}
\hline O ccupation & Prop. of women \\
\hline Science: Technical & 0.111 \\
\hline Science: Chemical and Biological & 0.612 \\
\hline M edicine, Health and Nursing & 0.880 \\
\hline Education & 0.703 \\
\hline Law & 0.299 \\
\hline R eligion, J ournalist, A rtist & 0.581 \\
\hline Administration: Government and Business & 0.465 \\
\hline Administration: Accounting, Clerical & 0.906 \\
\hline Administration: Other & 0.448 \\
\hline Sales: (business services, purchase, goods) & 0.385 \\
\hline Sales: Other & 0.542 \\
\hline A griculture, Horticulture, Forestry: Management & 0.117 \\
\hline Agriculture, Horticulture, Forestry: Workers & 0.295 \\
\hline W ildlife P rotection, Hunting and Fishing & 0.038 \\
\hline Mining & 0.027 \\
\hline Transport and Communication: Air, Sea, Other & 0.189 \\
\hline Transport and Communication: Drivers, Delivery & 0.077 \\
\hline $\begin{array}{l}\text { Transport and Communication: Postal Servcie, } \\
\text { Telecommunication }\end{array}$ & 0.579 \\
\hline M anufacturing: Textile & 0.658 \\
\hline M anufacturing: I ron and Metal & 0.071 \\
\hline M anufacturing: Precision-tool & 0.400 \\
\hline M anufacturing: Workshop and Construction & 0.104 \\
\hline M anufacturing: Electrical & 0.147 \\
\hline M anufacturing: Wood & 0.146 \\
\hline M anufacturing: Painting and Varnishing & 0.027 \\
\hline M anufacturing: Other Construction and Building & 0.003 \\
\hline
\end{tabular}




\section{Table A 3. Continued.}

\begin{tabular}{lc} 
Occuaption & Prop. of women \\
\hline & \\
Manufacturing: Graphics & 0.262 \\
Manufacturing: Glass, Pottery, Tile & 0.292 \\
Manufacturing: Dairy & 0.286 \\
Manufacturing: Chemical Processing & 0.256 \\
Manufacturing: Material Handling & 0.049 \\
Manufacturing: Packing and Storage & 0.296 \\
Manufacturing: Other & 0.317 \\
Services: Civilian Protection & 0.182 \\
Services: Lodging and Catering & 0.767 \\
Services: Caretaking and Cleaning & 0.603 \\
Services: Military & 0.037 \\
Services: Other & 0.677
\end{tabular}


Figure 1. Experience-earnings profiles for women in female and male dominated occupations.

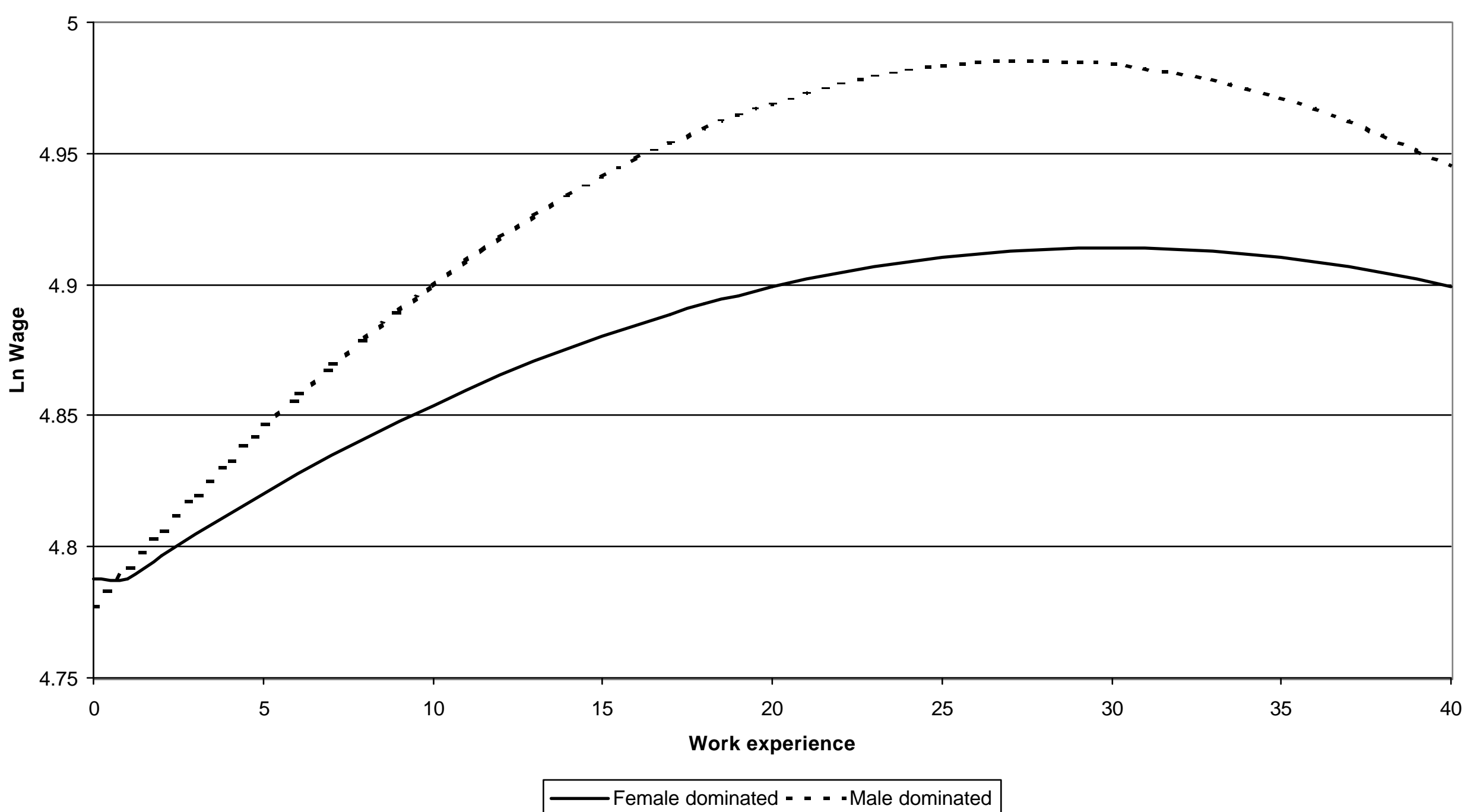




\section{IZA Discussion Papers}

\section{No Author(s)}

121

J. C. van Ours

122

D. Munich

J. Svejnar

K. Terrell

123 J. Hunt

124 R. T. Riphahn

125 F. Büchel

J. R. Frick

\section{J. Fersterer}

R. Winter-Ebmer

M. Karanassou

D. J. Snower

O. Ashenfelter

D. Ashmore

O. Deschênes

B. R. Chiswick

M. E. Hurst
G. Brunello
S. Comi
C. Lucifora

131 B. R. Chiswick

R. A. Hart

D. N. F. Bell

R. A. Hart

O. Hübler

W. Schwerdt

134 A. D. Kugler

G. Saint-Paul

135 A. Barrett

P. J. O'Connell

136 M. Bräuninger

M. Pannenberg

Titel

Area

Date

Do Active Labor Market Policies Help Unemployed $\quad$ 4/6

$3 / 00$

Workers to Find and Keep Regular Jobs?

Returns to Human Capital under the Communist

4

$3 / 00$

Wage Grid and During the Transition to a Market

Economy

Why Do People Still Live in East Germany?

$3 / 00$

Rational Poverty or Poor Rationality? The Take-up 3

$3 / 00$

of Social Assistance Benefits

The Income Portfolio of Immigrants in Germany -

$1 / 3$

Effects of Ethnic Origin and Assimilation. Or:

Who Gains from Income Re-Distribution?

Smoking, Discount Rates, and Returns to

5

$3 / 00$

Education

Characteristics of Unemployment Dynamics: The

Chain Reaction Approach

Do Unemployment Insurance Recipients Actively

Seek Work? Evidence From Randomized Trials in

Four U.S. States

The Employment, Unemployment and

Unemployment Compensation Benefits of Immigrants

The Returns to Education in Italy: A New Look at 5 the Evidence

$3 / 00$

Are Immigrants Favorably Self-Selected? An $\quad 1$

$3 / 00$

Economic Analysis

Hours and Wages in the Depression: British 7 Engineering, 1926-1938

Paid and Unpaid Overtime Working in Germany and 1 the UK

Hiring and Firing Costs, Adverse Selection and

Is There a Wage Premium for Returning Irish

1

$3 / 00$

Migrants?

Unemployment and Productivity Growth: An

3

$3 / 00$

Empirical Analysis within the Augmented Solow Model 
139 R. A. Hart

Y. Ma

140 G. Brunello

S. Comi

141 R. Hujer M. Wellner

142 J. J. Dolado

F. Felgueroso

J. F. Jimeno

143 P. J. Luke

M. E. Schaffer

144 G. Saint-Paul

145 M.-S. Yun

146 T. K. Bauer

J. P. Haisken-DeNew

147 M. Belot

J. C. van Ours

148 L. Goerke

149 R. Lalive

J. C. van Ours

J. Zweimüller

150 J. DiNardo

K. F. Hallock

J.-St. Pischke

$151 \quad$ M. Ward

152 J. J. Dolado

F. Felgueroso

J. F. Jimeno

153 A. S. Kalwij

M. Gregory

154 M. Gerfin

M. Lechner
Wages, Hours and Human Capital over the

Life Cycle

Education and Earnings Growth: Evidence from $11 \quad$ 2/5

European Countries

The Effects of Public Sector Sponsored Training on Individual Employment Performance in East Germany

Explaining Youth Labor Market Problems in Spain: 3 Crowding-Out, Institutions, or Technology Shifts?

Wage Determination in Russia: An Econometric 4 Investigation

Flexibility vs. Rigidity: Does Spain have the worst of 1 both Worlds?

Decomposition Analysis for a Binary Choice Model 7

Employer Learning and the Returns to Schooling 5

Does the Recent Success of Some OECD

Countries in Lowering their Unemployment Rates

Lie in the Clever Design of their Labour Market

Reforms?

Employment Effects of Labour Taxation in an Efficiency Wage Model with Alternative Budget Constraints and Time Horizons

The Impact of Active Labor Market Programs and Benefit Entitlement Rules on the Duration of Unemployment

Unions and the Labor Market for Managers

Gender, Salary and Promotion in the Academic Profession

The Role of the Minimum Wage in the Welfare 3 State: An Appraisal 
A Comparison of the Human Capital and Signaling Models: The Case of the Self-Employed and the Increase in the Schooling Premium in the 1980's

162 C. Dustmann M. E. RochinaBarrachina

Public Employment and Redistributive Politics: 4 
174 E. Fehr J.-R. Tyran

175 M. Lofstrom

176

O. Hübler

W. Meyer

177 B. R. Chiswick

G. Repetto

178 R. Euwals

M. Ward

179 E. Wasmer

P. Weil

180 T. K. Bauer

I. N. Gang

181

E. Wasmer

Y. Zenou

182 M. Fertig

C. M. Schmidt

183 M. Fertig

C. M. Schmidt

184 M. Corak

B. Gustafsson

T. Österberg

185 H. Bonin

K. F. Zimmermann

186

C. Dustmann

187

T. K. Bauer

M. Lofstrom

K. F. Zimmermann
Does Money Illusion Matter? An Experimental Approach

Self-Employment and Earnings among High-

Skilled Immigrants in the United States

Industrial Relations and the Wage Differentials

between Skilled and Unskilled Blue-Collar

Workers within Establishments: An Empirical

Analysis with Data of Manufacturing Firms

Immigrant Adjustment in Israel: Literacy and

Fluency in Hebrew and Earnings

The Renumeration of British Academics

The Macroeconomics of Labor and Credit Market Imperfections

Sibling Rivalry in Educational Attainment:

The German Case

Space, Search and Efficiency

Discretionary Measures of Active Labor Market Policy: The German Employment Promotion Reform in Perspective

Aggregate-Level Migration Studies as a Tool for 1 Forecasting Future Migration Streams

Intergenerational Influences on the Receipt of Unemployment Insurance in Canada and Sweden

The Post-Unification German Labor Market

Temporary Migration and Economic Assimilation

Immigration Policy, Assimilation of Immigrants and Natives' Sentiments towards Immigrants: Evidence from 12 OECD-Countries

The Myth of Worksharing

A. S. Kalwij

A. Zaidi

189

W. Arulampalam
5

2

$8 / 00$ 3

4

$8 / 00$

$8 / 00$

5

$8 / 00$

$7 / 00$

$7 / 00$

$7 / 00$

$7 / 00$

$7 / 00$

$8 / 00$

$8 / 00$

$8 / 00$

$8 / 00$

$8 / 00$

$8 / 00$

3

$8 / 00$
Is Unemployment Really Scarring? Effects of

Unemployment Experiences on Wages 
190 C. Dustmann

I. Preston

191 G. C. Giannelli

C. Monfardini

192

G. Brunello

193

A. Kunze

194

A. Newell

F. Pastore

195 F. Büchel

A. Mertens

196 J. S. Earle

K. Z. Sabirianova

197

G. A. Pfann

198 M. Kreyenfeld

C. K. Spiess

G. G. Wagner

199 H. Entorf

200 T. Bauer

G. S. Epstein

I. N. Gang

201 T. J. Dohmen

G. A. Pfann

202 P. Francois

J. C. van Ours

203 J. M. Abowd

F. Kramarz

D. N. Margolis

T. Philippon

204

G. S. Epstein

205

A. L. Booth

M. Francesconi

J. Frank

206 C. M. Schmidt

R. Baltussen

R. Sauerborn
Racial and Economic Factors in Attitudes to

1

$8 / 00$

Immigration

Joint Decisions on Household Membership and

Human Capital Accumulation of Youths: The role of

5

$8 / 00$

expected earnings and local markets

Absolute Risk Aversion and the Returns to

5

$8 / 00$

Education

The Determination of Wages and the Gender

Wage Gap: A Survey

5

$8 / 00$

Regional Unemployment and Industrial

4

$8 / 00$

Restructuring in Poland

Overeducation, Undereducation, and the Theory

of Career Mobility

5

$9 / 00$

Equilibrium Wage Arrears: A Theoretical and 4

Empirical Analysis of Institutional Lock-In

$9 / 00$

Options to Quit

$9 / 00$

A Forgotten Issue: Distributional Effects of Day

3

Care Subsidies in Germany

$9 / 00$

Rational Migration Policy Should Tolerate Non-

$9 / 00$

Zero Illegal Migration Flows: Lessons from

Modelling the Market for Illegal Migration

What are Migration Networks?

$9 / 00$

Worker Separations in a Nonstationary Corporate 1 Environment

$9 / 00$

Gender Wage Differentials in a Competitive Labor 5

$9 / 00$

Market: The Household Interaction Effect

The Tail of Two Countries: Minimum Wages and 5 Employment in France and the United States

$9 / 00$

Labor Market Interactions Between Legal and

1

$10 / 00$ Illegal Immigrants

Temporary Jobs: Stepping Stones or Dead Ends? $\quad 1$

$10 / 00$

The Evaluation of Community-Based Interventions: Group-Randomization, Limits and

6

$10 / 00$ Alternatives 

Germany- The Firms' Viewpoint 